\title{
Impact of Career Salience on Employees Job Involvement, Analyzing the Moderating Role of Organization Citizenship Behavior
}

\author{
ROQIA MALIK \\ Shaheed Zulfiqar Ali Bhutto Institute of Science and Technology, Islamabad \\ DR. MUHAMMAD ZIA-UR-REHMAN \\ National Defense University, Islamabad \\ DR. FAHAD SULTAN \\ Assistant Professor, Institute of Business Studies and Leadership \\ Abdul Wali Khan University, Mardan \\ MOHAMMAD UMAIR KHAN \\ Research Assistant, Institute of Business Studies and Leadership \\ Abdul Wali Khan University, Mardan
}

\begin{abstract}
The current study identifies the factor that affecting the organization citizenship behavior and its employee's job involvement. The study gives significance value to the literature that it provides compete discussion and information on organization citizenship behavior and its antecedents and consequences. The purpose of the study is to find out the impact of career salience on employees job involvement, analyzing the moderating role of organization citizenship behavior. Questionnaire method is used for data collection. Researcher collects the data from middle and lower level of employees on different organization. The total 44 questions asked from the middle and lower level of employees in Rawalpindi Islamabad Pakistan. The total data was collected through questionnaire from sample of 250 individuals and total 240 of respondent data was used for analysis. The result of this study indicated that there are significance relationship between independent and dependent variables and moderation was checked through (Baron \& Kenny, 1986) condition. To test the reliability of the items cronbach's alpha was used and testing the hypothesis of the study regression analysis was used. Further result show that the career salience, employees job involvement mediating effect of organization citizenship behavior.
\end{abstract}

Keywords: career salience, employee's job involvement, organization citizenship behavior 


\section{Introduction}

\subsection{Background}

Some organization have small prospect for development occupational in the employee career in Pakistan and employees is limited performance because the organization give to employee less training and career development therefore, the career development is compulsory part of knowledge and awareness. The (patton, 2001) says about the career development help the individual employees before joining the organization till giving up work. Career salience is influence by attitude of people who working at the same workplace so there must be strong relationships between the interaction and culture. 1990's during a number of comparative researcher had been performed the career salience.(Morrow and McElroy, 1986) found that the career salience to be postitvely related to work, work as a central life interset, job involovement and organizational citizenship behavior. The researcher investigation that the relationship between the job involvement and job performance that is not measure with work centrality and ratings the supervisory performance (Paullay et al., 1994) Organ's (1988) consistent the aspect of performance with the conceotualization of organizational citizenship behavior. In general role performance differ from of organizational citizenship behavior in to main respect, (Organ , 1997) unlike in organizational ciizenship behavior and role performance technic core do not direct support, but organizations influence the social and psychological of environment which influences the technical core. That is producing goods and services in involve the role behavior and maintaining over time this producing, the technical core operates in which the psychological environment enhance organizational citizenship behavior (Motowido et al., 1997).

The organizational effectiveness to contribute behavior than indirectly operate organizational ciyizenship behavior and directly operate task perfprmance. Podsakoff and Mackenzie (1997) organizational citizenship behavior describe friction reducing, or increasing effciency this aspect of the social machinery of the organization, and researcher study organizational citizenship behavior the task features by work process technology and less constrained then the role activities. Work process technology and ability is influenced by individual task performance, when individual are influenced organizational citizenship behavior than employee think and feel about their jobs (Organ and Ryan, 1995; Penner et al., 1997). Brown's (1996) suggest that no significant of job involvement and the relationship between overall job involvement and job performance, the researcher argue that this studies included job performance conceptualized in the terms of organizational citizenship behavior. The job involvement to br an important determination of motivation though of effort, positively job attitudes has been related to organizational citizenship behavior, job involvement is anticipated that those high engage in more organizational citizenship behaviors (Van Scotter, 2000). Even the individual are not assigned duties beacause thay are a part of organizational citizenship behavior, when employees are members themselves than the organization are still benefical (Van Scotter et al., 2000); therefore individual highly involved in the behaviors then the should engege to less involved to a greater extent individual.job involvement the degree which which a person perceives to be important and to be central the total work situation to his / her identity because the offorded to the opportunity to important satisfy needs. Jacqueline et al. 2004) refers an extra role behavior to be organizational citizenship behavior it is not 
officially required behavior for the organization rather than its depended solely on the employee practice on the consent of the organizational as consequence environmentm. The impact on organization effectiveness makes the organizational citizenship behavior; the impact on the organizations effectiveness should have a particular organizational citizenship behavior the social framework by adding the work environment (Todd, 2003). Employees highly involved their jobs connected to their diverse interests and life goals,as well as they satisfaction to their duity than thay performing effectively. More persons are invovled more competent and successful at work believe that their organizational goals are attribute positive outcomes and personally to their work internal controllable factors. Organizaton need to achive the highest degree of job involvement or improve the employees level. Although a high degree of job involvement are aspire to encourage of organization, its extremely difficult effort because the largely differences in the degree of employees among job involvement. These differences a key individual variable, in personality variation. (Lee, 2004) the postive relationship between the employees and transformational leadership and efective the comitment and also proved that there is direct impact of organizational citizenship behavior on job involvement and job involvement on employees career salience. (Evans, 2000) mention that the organizational citizenship behavior improved performance of job interset,job involvement.

Blau and Boal (1989) concluded that the organizational citizenship behavior and job involvement have less absences with more level of employees while the organizational citizenship behavior and job involvement have more level of absencesthan less degree of employesss. (Ting, 2011) mention that the direct impact of organizational citizenship behavior and job involvement. Kiyani et al. (2011) the relationship between the career salience and job involvement have positive significant. The concept of career salience is importance to telative to work and career, overall work attitude and concern for progress and planning. The fundamental of profession major flexibility as one of career salience. The concept of (Savickas, 2002) career salience a lot of attention and the particularly career literature in the development of women career. (Greenhaus, 1987) describe the employees authority of position basically hold by in specific organization an individual career whereas each organizatuin performs of individual specific duty. Holmes and Cartwright (1993) concluded that a successive and arranged is an expectable of career path which allows different stages to pass through of professional lives. So skills and knowledgy individual should be keep in order with the rapidly changing environment. Individualized consideration by employees can be benefitted through supporting and coaching them. (Bass, 1985) foucs on logical consideration and employee's and taking their suppositions can be boost up the intellectual stimulation morale of employees. The impact of organizational culture had any impact on career salience an employee's. The researcher studies that the managers in managing career salience of identify employees for avoiding problem. Organization would finding enable in adjusting plan to the organization culture so that the employees career as the most important object.

\subsection{Identification of Gap}

The gap in this research is identified from the previous research studies. (Athanasou, 2003)Studies that positive relationship between the career salience with the job involvement that the plays significant role of career knowledge for job involvement. Paullay et al.'s (1994) check the relationship the career salience performance with the job 
involvement and they suggest that the moderation occur between the career salience and the employee's job involvement.

\subsection{Problem statement}

The organizations spend their scarce resources on organization of their employees so that the employees can better handle their work and can efficiently and effectively contribute in achievement of overall strategic goals of the organizations. If the organizations do not spend on the resources of their employees then neither the employees involve their job and can grow nor the organizations. When the employee is involve their job than the present level of employees to a desired level. At the same time, if the organizations do not offer incentives to workforce then the trained employees may leave this organization for better personal opportunities and thus intentions of critical employees to leave the organization pose an internal threat to the organization than the researcher analyze and evaluate in the interaction between the career salience and employee job involvement and the moderating role with organizational citizenship behavior.

\subsection{Objectives of the Study}

Researcher found that the career salience to be postitvely related to work, work as a central life interset, job involovement and organizational citizenship behavior. job involvement although to be a key factor and considered individual and organizational out come in influencing the non significant relationship between the overall job performance and job involvement and concluded indirect performance which may affect the job involvement.

\subsection{Research Questions}

How career salience effect the employee job involvement?

How organizational citizenship behavior modere the relationship of career salience and job involvement?

\subsection{Significance of the Study}

Stump (1987) Define the career salience is the "perceived importance of work in occupational choice and satisfaction. Career salience deals with the worth of work and career with the relative in an individual entire life Masih (1967) the career salience is the degree of attentiveness in ruthless occupation that displays a person degree, prominence to her / his profession for the sake of satisfaction that is assigned to career as character of satisfaction and level of distinction which among other fundamentals of satisfaction. According to Kiyani et al. (2011) career salience found that the positive relationship has significant with the job involvement of public and private universities teachers. According to Rabinowitz and Hall (1977) job involvement is variable difference an individual whether person an attribute primarily or a response to the work environment. In particular a high degree of job involvement (JI) of organization effectiveness which any effort to maximze a member of an organization (Elankumaran, 2004).

Job involvement as a central life interset work of the degree regards the work situation which a central important of person identity because the satisfy of opportunity to main needs. Ryan (1997) argu that job involvement and organization performance are related negatively as well as empolyees leaving work early and positively related job envelovement to work effort and performance. Accroding to Blood the construct of middle class work value who would rather have job that there are workers which do not demand personal involvement. Organizational citizenship behavior is define conceptually 
as the individual energy investment and resources required beyond the organizational norms (McAllister, 1995; Organ 1988). The organizational treatment is individual engage as a form of reciprocity based on organizational citizenship behavior (Jacqueline et al. 2004). Organizational citizenship behavior is not formally ans extra role behavior evalvated (Pond et al. 1997). Organizational citizenship behavior concepts is parallel to management evaluate have not been development behavior (Barker, 1993). According to the Whiting et al. (2008) organizational citizenship behavior are often indicated to workshop which equally important performance appraisals as actual task performance. Job involvement is also contributes in the modern economic era to the overall human resources of availability (Gore, 2001). For instance Barnard (1938) the organization is indispensable willingness to contribute individual to effective efforts attainment of organzational goals. Organization job performance can be enhance the potential of employee work place by making atmophere and motivation involvement which may be the important role play by competitive business world. Job involvement as a central life interest work of the degree regards the work situation which a central important of person identity because the satisfy of opportunity to main needs.

\subsection{Delimitations}

Researchers states that there are many other variables that to be tested as antecedent an consequences of organizational citizenship behavior like it should be tested with work ordination, personality, energy level, and personal control. (Lambert, Hoghan, \& Barton, 2004). For the generalization of the research finding its suggested that in future the research should be tested in qualitative and quantitative techniques like interviewees and longitudinal surveys.

\section{Literature Review}

2.1 Career Salience

According to (Greenhaus, 1971) the concept of career salience and job involvement is (perceived importance of work and a career in one's total life). (Stumpf, 1987)Define the career salience is the "perceived importance of work in occupational choice and satisfaction". Career salience was also related to be positively expected to women's level of education (Awe, 1991; Ogundipe-Leslie \& -Leslie, 1985; Parpart, 1990). Career salience deals with the worth of work and career with the relative in an individual entire life. If researcher was negatively expected than the family size is related to the family career salience because the women require more time from large family ( Johnson, , 197 ; Farooq, 1987; Parpart, 1990). If the women are agree that a married women's and male colleague's are more moderate of the career goals. This is the expection of males and femals career goals (Bappa et al, 1985). The family size and the women's educational level are related to their career salinence. The women give to opportunity to participate the work force but the work force are irrespective of the educational level. However the women career salience postivel releted to the level of education. The postgradute and profassional level of males and femals are usually involved in their jobs which are education and training (Suitor, 1988). The reascher find that the men advencement is so faster, with the greater compenation (phillips \& lmhoff, 1997). The researcher study that the career salience and gender issue which is related to interprets an individual percives a career. Accrodind to the researcher men career oriention than their female counterparts. Researcher finding that men and women importance the same place on their career. The 
researcher related to career salience in women and men ideology. Career salience related to the relationship lower in women but did not affect the men factor of career salience (Moya, Exposito, \& Ruiz, 2000). Woman's has no guarantee of future performance they provides current performance because they change unepectedly her family status ((Rosenfeld, 1980). The personal goals as well as attachment of career development, identification with the inovelement in those goals (Corarelli \& Bishop, 1997).

Carrer saliance to contribute the genderd pattern of occupational choices and educational which raning of the social nature (labor force and gender perception). The career of important degree in one's life is known as career salienace. The career salience mean in individual comes into the room and career about his / her cares of it. Career salience deals with thr career in an individual and related work of worth in entir life. For instance the career saliance suggest that woman do not advance because of an artifical barrier of the organization constrain them. The important role of career that the role played individual such as work in family in various domian (Super, 1990; Super, Savickas, \& Super, 1996). Salience refers to 'the extent of career central which person sees involvement to his or her adult life role. The empolyee of organization by stimulating their of career salience. Masih (1967) the career salience is the degree of attentiveness in ruthless occupation that displays a person degree, prominence to her / his profession for the sake of satisfaction that is assigned to career as character of satisfaction and level of distinction which among other fundamentals of satisfaction. The concept of career salience and the career development which has received a lot of attention in the particulary career literature of women (Savickas,2002). Career salience was consider as the degree of career one's life. Its depened the career how much individual cared about his/ her life. Career describe the factors and processes that individual influence career behavior. According to Kiyani et al. (2011) career salience found that the positive relationships has significant with the job involvement of public and private universities teachers. We were getting help from career salience most of employees agreed that they maintain their job involvement. Most of reschers found that the career salince may be helpful in involvement the job.Sekaran,s (1982)the career salience of dual career familes means men and women relationship of the work modern outlookwhich entails increasing number of women apply the career salience to the workforce. The career salience tahat better define that the career is sound relationship with the job involvement.Stumpf and Lockhart (1887) argue that the career salience is (perceived importance of occupational choice work and satisfaction.

\subsection{Employee Job Involvement}

Lodahl and Kejner (1965) define job invlovement as the degree of worker experciences of daily absorption in his or her work activity; it reflect whether the main foci of person consciousness and considers work affirmation. Job involvement refer to self esteem which a person depends on his or her work efficiency. According to Rabinowitz and Hall (1977) job involvement is variable difference an individual whether person an attribute primarily or a response to the work environment. Rabinowitz,Hall and Goodale (1977) are equally important of personal and environmental variable, Newton and Keenan (1983) though indicate that the job involvement can better predict of environmental variable, according to (McKelvey \& Sekaran, 1977) personal attributes are more relevant. Job involvement can explain the work environment factor and personal attributes. Overall research assume that job involvement is an higher desirable attribute of employees 
(Mudrack, 2004). Human behavior plays a significant role of technological development, regardles in maximizing for organization effectiveness. In particular a high degree of job involvement (JI) of organization effectiveness which any effort to maximze a member of an organization (Elankumaran, 2004). That is an important motivational variable of job involvement for any organization. Job involvement is also contributes in the modern economic era to the overall human resources of availability (Gore, 2001). For empolyees interset, identities, and life goals are highly involved their job seem as well as thay connected satisfaction their job duties performing from effectively. (Brown, 1996) first identified job involvement over 35 year ago as an important for organizational attitude and they have been measurment inconsistencies in its conceptualization (Lodahl and Kejner, 1965). "central life interest"as job involovement conceptualized as the degree which the total job situation (Dubin, 1956,1986). It is perceived the degree which to be major sourec of important needs for the satisfaction.

Wickert suggested that the job involnement could me measure the degree which empolyee feels that he or she is actively in his job participating. (French and kahn, 1962) conceived the degree of job involvement which perceived the empolyee central job performance to his self concept,its effects the degree of self esteem. Accroding to (Siegel, 1969)the important of work to a person's that job involvement or sense of worth of self esteem. (Iverson and Reuder, 1965) studies that the terms of job involvement is the relationship of empolyee performance and job evaluation. (Hackman, 1968) suggest that tha defect and management in zore operates by objectives programs which the empolyee commit on her job involvement himself to getting goals he set for homself. Vroom considered the existing of self conception which consistency of job performance. Lodahl and Kejner's (1965) define the job involvement it is the term that the evident "work" is used instead of "job". job involvement is the out comes of the organizational behavior and job performanace is measure the employees duties of one's job. Organization job performance can be enhance the potential of employee work place by making atmophere and motivation involvement which may be the important role play by competitive business world. Kanunge define the job involvement in his study the job involovement was the identification of a "psychological" with one's work. Job involvement shown to be related situational variable which include challenging workand participation in decision making ,job satisfaction and decision career freedom of choice, a confident and trusting leader (Hall, Googale, Rabinowitze \& Morgan 1978). According to the (Rabinowitz and Hall 1977) that the job involvement is "variable feedback", which cause and effect of simultaneously job behaviour. Researcher has focused in the cause of job invelovement on the employee job performance. Kanungo (1982) job involvement is a psychological identificantion of cognitive or belief state with one's job. (Brown, 1996) suggest that job involvement will be the highest work when we make belive that work envorinvment its one's work is meaningful; how work is accomplish over control offers; norms are clear set of behaviour; work avilable an concerning completed makes feedback; and supervisor provides the supportive with the co worker.

According to the individual job involvement is the important of value about to the internalization work. A function of current job which how much the job can satisfy one's wishes. The central part of individual job which highly job involvement of their personal character. Highly job involvement with besides people focus most of their attention on 
their job (Hackett et al., 2001). Job involvement is highly participation in the job an $\mathrm{d}$ the opportunity to make job decision, an important to company goals to make contribution, and self determination. Job involvement and organizational performance both of high level with individualthe most motivated should be go to work and to go on time. Individual should be least motivated with the low level of job involvement and organization commitment. Job involvement and organization commitment both are higher levels of individual if employees are lateness, unexcused and absence with lower level of job involvement and organization commitment (Blau, 1986; Blau \& Boal, 1987). (Repetti, 1984) the employees of mental health which is related social environment and the high quality of work. These studies compare to the primarily levels of job involvement and memtal health of the employees. Brown (1996) and Paullay et al (1994) both are argued that this measure job involvement conceptually confounds with work centrality.

The most important things in his / her life low level of work centrality that a person should be indicated a high level of job involvement because he and she should work activity and thing about work issue. (Brown, 1996) reported that job involvement is fact of work centrality and represent different construct,and contributed to the non significant relationships with performance. (Pauallay et al 1994) job involvement of measure deveploped and factorially distince are that work centrality. Job involvement would be related community size negatively and that participation decision making the relationship between the job invlovement and individual would be more positive smaller communities and rural area. Community size are related positively job involvement and the relationship between the more positively participation job involvement for urban employees than less than more urban employees. Accroding to the (Bass, 1965) the opportunity of high job involvement to make job decision, an important contribution that the feeling one is making company success and self determination. The individual perceived more trust non work experience pressures they were findly support more likely their group.

\subsection{Organizational Citizenship Behavior (OCB)}

(Organ, 1997) Organizational citizenship behavior (OCB) is define the social and psychological environment that performance supports in which task performance takes place. Organization behavior is beneficial of workers denote the organizational citizenship behavior that was not preacribed help others but occure freely to achive the task at hand (Bateman \& Organ, 1983). The researcher argue that "the organization lubricate is social machinery". The formal participants to beyond exert effort has long recognized of their positions as an esential component of organizational effective performance. Graham (1991) argued that the global concept of the organizational citizenship behavior should be positive which includes conceptualized organization behaviors related of individual organization members. Thus conceptualization organization behavior broader includes job performance behavior, extra role organizational functional behavior, such as organizational responsible full participation . Researcher propsed and tested organizational citizenship behavior conceptualization based on an political philosophy of application to organizational settings. Organizational citizenship behavior is describe to which are willing menbers to "the call above of go duty" in organizational success that contribute act performaing. Organizational 
citizenship behavior is define conceptually as the individual energy investment and resources required beyond the organizational norms (McAllister, 1995; Organ 1988). Organizational citizenship behavior is related to organizational behavior. The organization closely related to organizational citizenship behavior concern directed toward motive organizational (Dick et al.2006).

Organizational citizenship behavior not on customer satisfaction but its impact on profitability. The organizational treatment is individual engage as a form of reciprocity based on organizational citizenship behavior (Jacqueline et al. 2004). Organizational citizenship were found subsequent to influence employee attitudes. Researcher arguments that organizational citizenship behavior view regarding also exist. Organizational citizenship behavior is not formally ans extra role behavior evalvated (Pond et al. 1997). Organizational citizenship behavior are likely more attention receiving work behavior as to effective contribute functioning of organization. Job behavior were initially define organizational citizenship behavior that are not recognized explicitly the reward system formal in the aggregate, organizational contribute to effectiveness (Organ, 1988). (Katz, 1964) suggest that the organizational citizenship behavior is importance os organizational effectiveness. Although organizational citizenship behavior a good deal with the development of organizational citizenship behavior theory conducted has progressed rather slowly. Ehigie and Otukoya (2005) analyzed the employees perceived fair interpersonal treatment and support organization, organizational citizenship behavior found that the employees interpersonal treatment which percevied organizational support and joint effect on independent organizational citizenship behavior. (Krishnan and Singh, 2010)show that organizational citizenship behavior intention of low level to quite result in high level of deviance organization.

Organ et al, (2006) the organizational citizenship behavior are related positively to organizational outcomes and performance appraisals. Job descripation are not a part of employees organizational citizenship behavior, researcher can mamagerial influence organizational citizenship behavior evaluations (Podsakoff et al., 2000; Whiting et al.,2008). Organizational citizenship behavior are essential employee influence evaluation include that organizational citizenship behavior belief to the success of the organization, organizational citizenship behavior being participation as percevied that organization voluntary, general expectation performed should be organizational citizenship behavior that aggregated to overall job performance (Organ et al., 2006). Organizational citizenship behavior concepts is parallel to management evaluate have not been development behavior (Barker, 1993). The concept of organizational citizenship behavior toward evaluating in the contemporay workplace in the role of management behavior. The concepts of worker citizenship behavior it's a parts of new concepts which can be used the one sided extending concept of organizational citizenship behavior. According to the Whiting et al. (2008) organizational citizenship behavior are often indicated to workshop which equally important performance appraisals as actual task performance. Organizational citizenship behavior engeging employees to do with cognitive fairness of evaluation of employees treatment by an organization. If organization engaging employees perceive treating justly fairly, than they are likely to reciprocate in organizational citizenship behavior. The low performance come from the withdraw, absenteeismand turnover increased the organizational citizenship behavior 
(Barling and Philips, 1993; Folger and Konovsky, 1989). When working environment fair perceive employees they will respond accordance with perform and social exchange more organizational citizenship behaviors.

\subsection{Theoretical Framework}

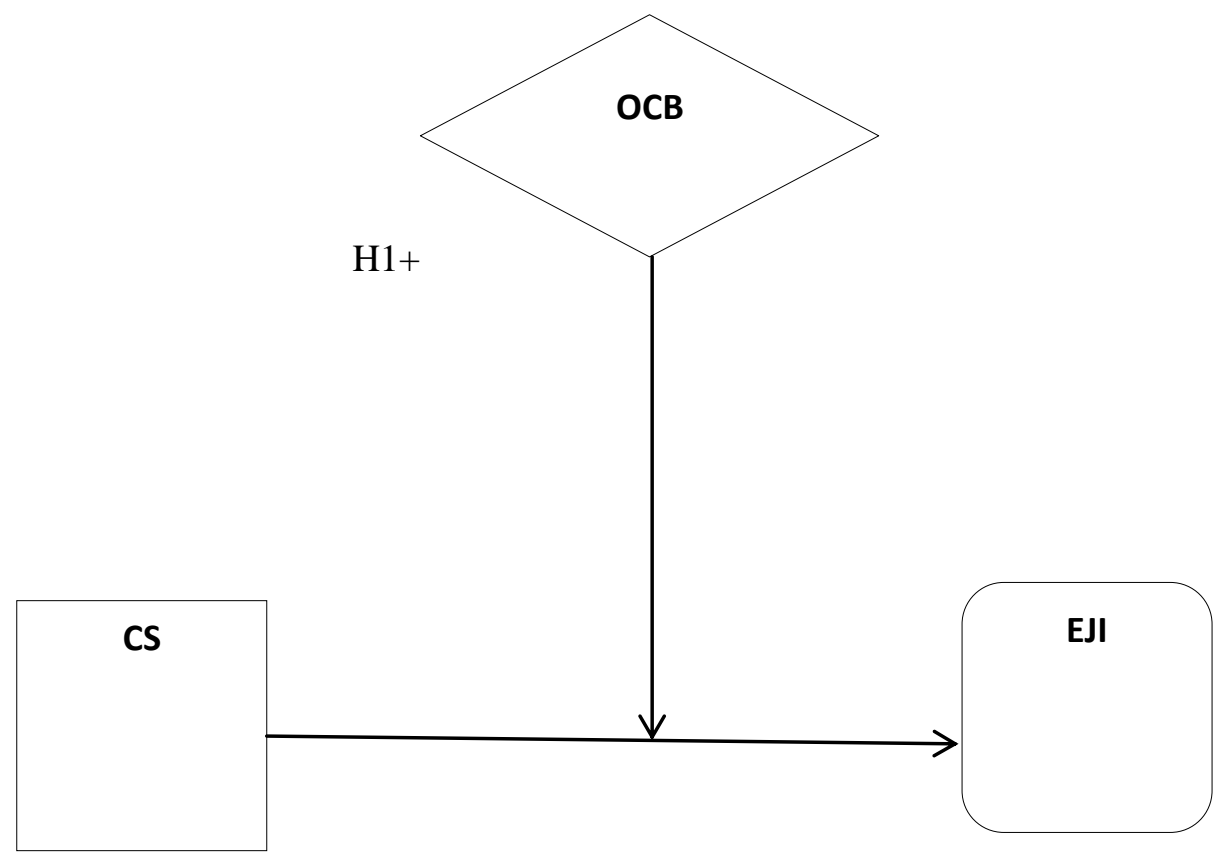

\subsection{Hypotheses}

$\boldsymbol{H}_{1}$ : Career salience has positive impact on employee job involvement.

$\mathrm{H}_{2}$ : Organizational citizenship behavior positively moderating relationship between the career salience and employee job involvement.

\section{Research Methodology}

\subsection{Research Design}

The present study is conducted to check the relationship between antecedents and outcomes of organizational citizenship behavior. This study tries in questions to describe the importance of organizational citizenship behaviors, its antecedent and outcomes.

\subsection{Population}

The populations of this research consist of career salience, employee job involvement analyzing the moderating role of organizational citizenship behavior in twin city of Pakistan Rawalpindi and Islamabad.

\subsection{Sampling Strategy and Data Collection Techniques}

For the hypothesis testing of this study, the researcher has selected the middle and lower level employees of the different organization. A survey of 250 questionnaire are filled from the middle and lower level of employees because these are the respondent' that are directly related to the contents of the questionnaire. The questionnaires were distributed 
in different organizations of employees who are involved in the organization. Out of 250 questionnaires was collected by responded in which 10 questionnaires were not filled correctly. A convenience sample of 240 questionnaires is used for analysis. The data was entered by the researchers themselves in the statistical software (SPSS) to ensure proper entry and confidentiality of data. The software used was SPSS version 20. Furthermore, it is user friendly and includes all the necessary features that we require for concluding our research. It is appropriate to use this software while testing causal relationships between variables. The process of running statistical tests on SPSS is easy and quick. In this study the SPSS, Regression Model was run for evaluating results.

\subsection{Unit of Analysis}

This is an individual study based on cause and effect, and aims at analyzing the career salience and employees job involvement in the moderating role of organization citizenship behavior. The study captures the perception regarding antecedent and outcomes of organizational citizenship behavior. Therefore the unit of analysis is individual.

\section{Results and Analysis}

Before the estimation of the model, it is necessary to check the validity and reliability of the questionnaire. As the researcher measures adapted from the previous studies, so content reliability test was used to check the internal consistency and reliability of the study. The reliability of questionnaire is found by using Cronbach's alpha. First, the reliability test was run for each variable separately, the Cronbach's alpha for career salience, employee's job involvement, and organizational citizenship behavior value was greater than the cut off criteria for scale reliability. After the reliability of all the variables was checked collectively, the $\alpha$ was equal to .903 which show that the questionnaire used in this study is reliable.

Table 1: Descriptive statistics

\begin{tabular}{lcccccccccrr}
\hline & N & \multicolumn{1}{c}{ Min } & \multicolumn{1}{c}{ Max } & \multicolumn{2}{c}{ Mean Std. D } & \multicolumn{2}{c}{ Skew } & \multicolumn{2}{c}{ Kurt } & \\
& & Stat & Stat & Stat & Stat & Std.Err & Stat & Stat & Std. Err & Stat & Std \\
Err & & & & & & & & & & \\
\hline SC & 240 & 2.29 & 4.71 & 3.5631 & 0.2758 & .42733 & .010 & .157 & 2.003 \\
.313 & & & & & & & & & \\
JI & 240 & 2.23 & 4.77 & 3.4558 & .03530 & .54680 & .058 & .157 & -.196 \\
.313 & & & & & & & & & \\
OCB & 240 & 2.50 & 4.90 & 3.7475 & .03095 & .47953 & .007 & .157 & .700 \\
.313 & & & & & & & & & \\
\hline
\end{tabular}

Skewness and kurtosis are the measure of the normality of the data (Sekaran, 2003). Value of Skewness should be between +1 to -1 to prove the normality of the data (Cooper, \& Schindler, 2008). In the table it is clear that all the values are within the range which proves the normality of the data. Kurtosis is also a measure of the normality of data.

Table 2: Factor wise Reliability 


\begin{tabular}{lcc}
\hline Name of the Factor & Cronbach's Alpha & No of items \\
\hline Career salience & .832 & 21 \\
Job involvement & .819 & 13 \\
Org citizenship behavior & .727 & 10 \\
Total & .903 & 44
\end{tabular}

It is basically a research instrument which shows that the instrument gives same results if the trials are repeated again and again. However unreliability exists to some extent, but the overall results that are gathered at different intervals of time shows consistency. This tendency which shows consistency is known as reliability (Sekaran, 2003).

The (table no 2) shows that the value of Cronbach alpha for all variables is greater than the 0.60 authenticating that the instrument is reliable for further statistical analysis. The overall reliability score for Cronbach alpha (.903) is higher than the acceptable standard of 0.60 (Nunnally, 1967; Hair et al., 1998; Leech et al., 2005), this study is findings would be reliable and generalize able for future references and indicating the internal consistency of the variable measures.

Table 3: Correlation

\begin{tabular}{llll}
\hline Career salience & jobinv & OCB & \\
\hline Career Salience & 1 & 1 & \\
Jobinv & $.531^{* *}$ & $.525^{* *}$ & 1 \\
OCB & $.647^{* *}$ & &
\end{tabular}

**Correlation is significant at the 0.01 level (2-tailed).

.Correlation shows that the variables have a relationship with each other. The Pearson correlation of coefficient value is between 0 to 0.3 then there exist a weak relationship between the variables. The Pearson correlation of coefficient value range is $0.3-0.7$ (Morgan et al., 2004) then there exists a moderate relationship. Zero value indicates that there is no relation among the variables (Morgan et al., 2004). Pearson Correlation was used to check the correlation among the variable. The (Table no 3) shows that the all variable are associated with each other and have significant correlation.

Table 4: Regression Analysis

\begin{tabular}{llrcccccc}
\hline IV & DV & R & $\mathrm{R}^{2}$ & Fstat & B & Beta & tvalue & sig. \\
\hline $\mathrm{CS}$ & $\mathrm{JI}$ & .531 & .282 & 93.694 & .680 & .531 & 4.096 & .0000 \\
\hline
\end{tabular}

**Significance level $\mathrm{p}<0.01$

Hypothesis No 1: Career salience has positive impact on employee job involvement.

Tables 4 demonstrate the basic results for simple regression. Referring to Table 5 which provide model summary value between the dependent (outcomes) and the independent (personal factor) variable i.e., R (.531). Accordingly, the R square value (.282) shows that $13.8 \%$ of the variance was explained in outcomes due to personal factor. Table 5 show ANOVA results for the regression model. İn this table, the $\mathrm{p}$ value (.000) corresponds to the F-statistic is less than the cut-off criteria $(p<.001)$ to reject the hypothesis. It allows us to conclude that there is enough proof existed to reject the null hypothesis in support of the alternative hypothesis that.

Table 5: Regression Analysis- Moderation Result 


\begin{tabular}{lccccccr}
\hline $\begin{array}{l}\text { IV } \\
\text { sig. }\end{array}$ & DV & R & $\mathrm{R}^{2}$ & Fstate & B & Beta & tvalue \\
\hline $\begin{array}{l}\text { IV } \\
.000\end{array}$ & MV & .647 & .419 & 171.513 & .726 & .647 & 13.069 \\
$\begin{array}{l}\text { IV } \\
.000\end{array}$ & DV & .525 & .275 & 90.410 & .598 & .525 & 9.508 \\
$\begin{array}{l}\text { CS } \\
.000\end{array}$ & & & & & & & \\
\\
\hline
\end{tabular}

** Significance level $\mathrm{p}<0.01$

Hypothesis no 2: Organizational citizenship behavior positively moderating relationship between the career salience and employee job involvement.

Firs the study found the simple regression to check the effect of independent variable (career salience factor) on depended variable (employee job involvement) shown in Table 5 then the Second, researcher have found the effect of independent variable ( career salience factors) on moderator (organizational citizenship behavior) Table 5 Third researchers have also found the effect of moderator (organizational citizenship behavior) on dependent variable (employee job involvement). Further, they have proposed that if all the predicated these conditions hold in directions, the last condition is "regressing the interaction effect of (personal factors) and (organizational citizenship behavior) on dependent variable (employee job involvement)". So researcher have taken the interaction of career salience factor and organizational citizenship behavior as an independent variables and employee job involvement as dependent variable see Table 5 that shows that the result of interactive variable on dependent variable that was $R^{2}=.344$ was increase to $\mathrm{R}^{2}=.419$ see Table 5 . Thus according is to the conditions if the $\mathrm{R}^{2}$ value increase then we can reject the null hypothesis in favor of alternative hypothesis that.

\section{Discussion}

The result of this study confirms the relationship and interaction of career salience, employee job involvement and the moderating role of organizational citizenship behavior. The researchers discuss the depended variable (employee job involvement factor), independed variable (career salience personal factors) and moderator (organizational citizenship behavior). These variables have the significance relationship which each other. In the first hypotheses is the Career salience has positive impact on employee job involvement. the first hypotheses accepted because the $\mathbf{B}$ value is .647 which show that if one unit change in independed variable will cause $64 \%$ change in depended variable and the value of $\mathrm{P}$ is less than 0.01 which show that their relationship between the variable. The second hypotheses Organizational citizenship behavior positively moderating relationship between the career salience and employee job involvement. Which is organizational citizenship behavior positivity moderates relationship between career salience factor and employee job involvement. The researcher runs the moderates through the Barron and Kenny (1986). The Barron and Kenny have four steps for the moderates which the researchers follow it. The variable is significance than the moderates are occurring. . The second hypotheses are significance and the moderate is occurring. In this study the hypotheses are accepted. These studies suggest that learning is very essential for the organizational employees. In today's knowledge driven environment of main function the organizational employees. The 
employees should be only focus on their career salience factors. Organizational citizenship behavior should use both the career salience fact and the employee job involvement outcome to acquire new knowledge and innovate the existing knowledge base using different types of knowledge, electronic information sources and observe practical works. The employees are happiness than they focus self-confidence, being free of stress, occupational career salience, family support and personal relation. The employees have too much workload actions in order to face successfully the fast changing environment and fulfill the reasonability of work and family requirements. The employee is the positive effect of the work life balance the benefits is universal experience of every individual employees. The employees have different types of work which is found the significant difference according to age and material status. The employees have a positive relationship between job involvement and work life balance. The employee's careers required the different experiences in the different situations. Employees have been the opportunities by jobs rather than career, on the career salience, employee job involvement factor rather than the long term benefit of outcome. The some employees who engage their job and focus to their work labor are likely to the stronger preferences of the workload of obligations. Organizational citizenship behavior has a moderating influence on employee action within the particular context. The employees, issues of affect the personality, cognition, and cognitive problem solving. The purpose of this study career salience, employee's job involvement hat is checking, if an individual employee experience work life balance then what is the hood that the employee will feel towards his work on the part of work life balance experience plays in the feeling of person being engaged to their work.

\subsection{Conclusion and Recommendation \\ 5.2 Managerial Implications}

The results and analysis of the study show some practical implication as well. As the employee is the hot issue in the organization in which is increasing day to day in organization so this study gives important information on barrier employees to minimize it by motivating them. The employees have a lot of responsibility because of which they do not give proper time to family. In particular, motivation to grow increases the recourse of organizational employees who help them to attain balance between work and family responsibility that will oblige them to reciprocate in kind with higher levels of education toward their work.

This study also shows that motivation to grow can be achieved by helping the employees to balance her family responsibility. In particular the higher education support for balancing work and family roles are more likely to reciprocate with greater level of education in their family. Motivation to grow an important role by making this relationship between career salience factor, employees' job involvement factor then the outcomes is more effective. The motivation to grow has stronger positive relationship between the career salience and organizational citizenship behavior. So if an employee is to achieve balance between his work and family life than we will be more engaged toward his work because he will be complete attention toward her work.

\subsection{Limitations of Research}

The results of this study should be considered by keeping its limitations in view. This study is relational in nature and only the questionnaire distribution middle and lower 
level of employees was used for data collection. Secondly, this study focuses on specific sector i.e. which the employee are work public and private in Islamabad Rawalpindi. Third, this study is limited to discussing the impact of career salience factors on employee's job involvement while there is other factors as well which in relationship with the career salience factors can affect the employee job involvement. Finally, because to time constraint data was collected from twin cities Rawalpindi and Islamabad only and sample size was small so a study with larger sample size can give concrete conclusion regarding the generalizability of the results.

\subsection{Future Research}

The future researches, researcher can focus the organizational citizenship behavior. In the future the researcher checks the organizational citizenship behavior as the mediator. In this study the researcher check the impact of career salience, employee job involvement analyzing, and the moderating role of organizational citizenship behavior. For the future researcher suggest that the check the relationship between the depended and independent variable but organizational citizenship behavior take as the mediator.

\subsection{Conclusion}

The purpose and objective of this study was to explore the gap. In this study researcher tried to identify the relationship and that how career salience factors has impact on employees job involvement. There is significant correlation found between the variables career salience factors, employees job involvement and organizational citizenship behavior. From the result of the study the independent variables career salience has positive relationship with dependent variable employee job involvement and the result also show significant role of the moderator organizational citizenship behavior between independent and dependent variables. Which show that the variables are correlated and affect each other. The whole study concludes that to minimize the impact of career salience and employee job involvement by helping them to balance her work and family and motivate them to every individual employee.

\section{References}

Barling, J., Slater, F., \&Kelloway, E. K. (2000). Transformational leadership and emotional intelligence: an exploratory study. Leadership \& Organization Development Journal, 21(3), 157-161.

Baron, Reuben M. and David A. Kenny (1986), "Moderator-Mediator Variables Distinction

Bergeron, D. M. (2007). The potential paradox of organizational citizenship behavior: Good citizens at what cost?. Academy of Management Review,32(4), 1078-1095.

Bhowon, U. (2013). Role Salience, Work-Family Conflict And Satisfaction Of DualEarner Couples. Journal of Business Studies Quarterly, 5(2).

Cameron, S. M., \& Nadler, J. T. (2013). Gender roles and organizational citizenship behaviors: effects on managerial evaluations. Gender in Management: An International Journal, 28(7), 380-399.

Chauhan, D. (2009). Effect of job involvement on burnout. Indian Journal of Industrial Relations, 441-453.

Cinamon, R. G. (2010). Anticipated work-family conflict: effects of role salience and self-efficacy. British Journal of Guidance \&Counselling, 38(1), 83-99. 
Comer, J. M., Ramsey, R., Lassk, F. G., \& Marshall, G. W. (1995). Methods in sales research: A critical evaluation of a measure of job involvement: The use of the Lodahl and Kejner (1965) scale with salespeople. Journal of Personal Selling \& Sales Management, 15(3), 65-74.

Diefendorff, J. M., Brown, D. J., Kamin, A. M., \& Lord, R. G. (2002). Examining the roles of job involvement and work centrality in predicting organizational citizenship behaviors and job performance. Journal of Organizational Behavior,23(1), 93-108.

Duffy, R. D., \& Sedlacek, W. E. (2010). The salience of a career calling among college students: Exploring group differences and links to religiousness, life meaning, and life satisfaction. The Career Development Quarterly, 59(1), 27-41.

Emami, M. (2012). The Relationship between Job Involvement, Job Satisfaction and Organizational Commitment among lower-level Employees.Asian J. Soc. Econ. Sci, 1(1), 23-33.

Erkutlu, H. (2011). The moderating role of organizational culture in the relationship between organizational justice and organizational citizenship behaviors. Leadership \& Organization Development Journal, 32(6), 532-554.

Ho, C. C., Oldenburg, B., Day, G., \& Sun, J. (2012). Work Values, Job Involvement, and Organizational Commitment in Taiwanese Nurses.International Journal of Psychology and Behavioral Sciences, 2(3), 64-70.

Hodson, R. (1999). Management citizenship behavior: A new concept and an empirical test. Social Problems, 460-478.

Hussain, S., \&Rafique, R. (2013).Role of Parental Expectation and Career Salience in Career Decision Making. Journal of Behavioural Sciences, 2Munson, $W . \quad W$. (1992).Self-Esteem, Vocational Identity, and Career Salience in High School Students. The Career Development Quarterly, 40(4), 361-368.3(2).

Johnson, P., Schamuhn, T. D., Nelson, D. B., \& Buboltz, W. C. (2014). Differentiation Levels of College Students: Effects on Vocational Identity and Career Decision Making. The Career Development Quarterly, 62(1), 70-80.

Kaplan, R. A., Boshoff, A. B., \& Kellerman, A. M. (1991). Job involvement and job satisfaction of South African nurses compared with other professions.Curationis, 14(1), 3-7.

Khan, T. I., \& Akbar, A. (2014). Job Involvement-Predictor of Job Satisfaction and Job Performance-Evidence from Pakistan.

Kiyani, A., Haroon, M., Khattak, M. A., Liaqat, A. S., Bukhari, S. J. A., \&Asad, R. (2011). Impact of career salience on universities teachers job involvement: A study on public and private universities in Pakistan. African Journal of Business Management, 5(5), 1795-1803.

Konovsky, M. A., \& Pugh, S. D. (1994). Citizenship behavior and social exchange. Academy of management journal, 37(3), 656-669.

Lambert, S. J. (2000). Added benefits: The link between work-life benefits and organizational citizenship behavior. Academy of Management Journal, 43(5), 801-815.

Liao, C., \& Lee, C. (2009). An empirical study of employee job involvement and personality traits: The case of Taiwan. International Journal of Economics and Management, 3(1), 22-36. 
Liou, k. T. (1997). An analysis of employees'job involvement in a community-based aids service organization. Journal of health and human services administration, 304-318.

Liu, Y., \& Cohen, A. (2010).Values, commitment, and OCB among Chinese employees. International Journal of Intercultural Relations, 34(5), 493-506.

Lobel, S. A., \& Clair, L. S. (1992). Effects of family responsibilities, gender, and career identity salience on performance outcomes. Academy of Management Journal, 35(5), 1057-1069.

McCook, K. D. (2002). Organizational Perceptions And Their Relationships To Job Attitudes, Effort, Performance, And Organizational Citizenship Behaviors(Doctoral dissertation, Louisiana State University).

Misra, S. B. (1979). Job Involvement and Alienation-Progress, Issues, and Prospects. Indian Journal of Industrial Relations, 501-515.

Moghadam, F. I., Moosavi, S. J., \& Dousti, M. (2013). The Relationship between Transformational Leadership and Organizational Citizenship Behavior of general office of Sport and Youth of Mazandaran Province. International Journal of Sport Studies, 3(7), 779-783.

Moorman, R. H. (1991). Relationship between organizational justice and organizational citizenship behaviors: do fairness perceptions influence employee citizenship?. Journal of applied psychology, 76(6), 845.

Moorman, R. H., Blakely, G. L., \& Niehoff, B. P. (1998). Does perceived organizational support mediate the relationship between procedural justice and organizational citizenship behavior?. Academy of Management journal, 41(3), 351-357.

Moya, M., Exposito, F., \& Ruiz, J. (2000). Close relationships, gender, and career salience. Sex Roles, 42(9-10), 825-846.

Munson, W. W., \& Strauss, C. F. (1993). Career salience of institutionalized adolescent offenders. The Career Development Quarterly, 41(3), 246-256.

Okocha, A., \&Perrone, P. (1992). Career Salience Among Nigerian Dual-Career Women. The Career Development Quarterly, 41(1), 84-93.

ÖZTÜRK, F. (2010). Determinants Of Organizational Citizenship Behavior Among Knowledge Workers: The Role Of Job Charcteristics, Job Satisfaction, And Organizational Commitment (Doctoral dissertation, Middle East Technical University).

Palmer, B., Walls, M., Burgess, Z., \&Stough, C. (2001).Emotional intelligence and effective leadership. Leadership \& Organization Development Journal,22(1), 5-10.

Rasool, S., Kiyani, A. A., Aslam, M. J., Akram, M. U., \& Rajput, A. A. Impact of Organizational Culture on Employee's Career Salience: An Empirical Study of Banking Sector in Islamabad, Pakistan.

Riaz, T., Ramzan, M., Ishaq, H. M., Akram, M. U., \&Karim, Y. (2012). Transformational leadership and employees career salience; an empirical study conducted on banks of Pakistan. International Journal of Business and Social Science, 3(8), 152-160.

Roffe, I. (1999). Innovation and creativity in organisations: a review of the implications for training and development. Journal of European Industrial Training, 23(4/5), 224-241. Ruh, R. A., White, J. K., \& Wood, R. R. (1975). Job involvement, values, personal background, participation in decision making, and job attitudes.Academy of Management Journal, 18(2), 300-312. 
Saleh, S. D., \& Hosek, J. (1976). Job involvement: Concepts and measurements. Academy of Management Journal, 19(2), 213-224.

Saleh, S. D., \& Hosek, J. (1976). Job involvement: Concepts and measurements. Academy of Management Journal, 19(2), 213-224.

Social Psychological Research: Conceptual, Strategic, and Statistical Considerations," Journal of Personality and Social Psychology, 51 (6), 1173-82.

Southgate, N. M. (2006). An exploration of career salience, career commitment, and job involvement (Doctoral dissertation).

Tang, S. (2010). Work support, work-family enrichment, work demand and work wellbeing among Chinese employees: a study of mediating and moderating processes.

Uarte, M. E. (1995). Career concerns, values, and role salience in employed men. The Career Development Quarterly, 43(4), 338-349.

Ullah, B. Z. (2009). Key antecedents of organizational citizenship behavior (OCB) in the banking sector of Pakistan. International Journal of Business and Management, 3(12), p106.

Uygur, A., \& Kilic, G. (2009). A study into organizational commitment and job involvement: An application towards the personnel in the central organization for Ministry of Health in Turkey. Ozean journal of applied sciences, 2(1), 113-125.

Van, D., L., Graham, J. W., \& Dienesch, R. M. (1994). Organizational citizenship behavior: Construct redefinition, measurement, and validation.Academy of management Journal, 37(4), 765-802.

Zainul, A. S. (2004). The Effect Of Personal Values On Organizational Commitment (Doctoral dissertation, Universiti Sains Malaysia). 